\title{
A Apologia de Palamedes à luz da Apologia de Sócrates - uma análise textual
}

\author{
JULIA GALVANHO MYARA
}

\begin{abstract}
RESUMO A partir da análise do texto Apologia de Palamedes, de Górgias, pretendo sustentar, com o apoio de uma rede de comentadores, o emprego que o personagem Palamedes faz de estratégias clássicas da retórica forense. Contudo, para além de uma mera apropriação genérica de tal retórica, o presente trabalho busca corroborar a tese que afirma a existência de forte relação entre a retórica na Apologia de Sócrates de Platão e a retórica na Apologia de Palamedes de Górgias. A partir de uma análise do texto gorgiano à luz do texto de Platão, busco defender não apenas uma semelhança entre ambos os personagens, mas uma similaridade na estratégia discursiva de ambos os autores, aproximando, assim, o exercício filosófico do exercício retórico.
\end{abstract}

PALAVRAS-CHAVE Retórica; Tribunal; Sócrates; Palamedes.

Dentro de uma longa tradição de retóricos gregos que produziram discursos de defesa em tribunais atenienses é possível reconhecer elementos e técnicas que também foram utilizados por Platão na Apologia de Sócrates. Para verificar a estruturação básica de discursos de tribunal nos restaram, por exemplo, textos de Lísias e Antífon, que nos mostram como tais organizações discursivas foram utilizadas antes de Platão ${ }^{1}$. Marina McCoy, dentre outros comentadores ${ }^{2}$, sugerem que existem importantes paralelos entre a Apologia de Sócrates, de Platão, e a Apologia de Palamedes, de Górgias. Dentre os principais, encontram-se afirmações sobre a natureza verdadeira

* Doutoranda PUC-Rio / Departamento de Filosofia Bolsista CAPES

1 McCoy, A retórica de filósofos e sofistas, p. 34.

2 Tais como Kenneth Seeskin, James Coulter e D.D. Feaver \& J.E. Hare. 
dos discursos de Sócrates e Palamedes, a piedade de ambos os personagens, a injustiça cometida contra eles, as mentiras e calúnias promovidas por seus opositores e a motivação duvidosa das origens das acusações.

A Apologia de Palamedes de Górgias é, antes de mais nada, um texto que simula a defesa do personagem mitológico Palamedes em um tribunal. Desse modo, para compreendermos mais claramente o texto de Górgias, é fundamental resgatarmos alguns aspectos essenciais do mito de Palamedes, cujas fontes mais antigas e confiáveis são os Cantos Cíprios de Estasino de Chipre3.

Palamedes, filho de Náuplio e Clímene, célebre pela sua criatividade e inventividade, deve sua fama, majoritariamente, ao seu papel nos mitos que envolvem a expedição à Troia ${ }^{4}$. A contribuição de Palamedes, embora de pouca importância durante a guerra ${ }^{5}$, foi a principal responsável pela ida de Odisseu à Troia, tornando-o conhecido na cultura grega ${ }^{6}$. Afinal, foi ele quem arquitetou e executou o desmascaramento de Odisseu.

Tendo em mente que a Apologia de Palamedes de Górgias foi escrita como um discurso fictício de defesa em um tribunal contra a acusação de traição promovida por Odisseu, deve-se notar que o mesmo texto, sendo uma peça retórica, utiliza-se amplamente de estruturas e estratégias recorrentes na retórica forense ${ }^{7}$. Ela simula o ambiente de um tribunal que é composto, como de costume, pelos jurados, o réu e o próprio acusador. A defesa de Palamedes é dividida de tal forma que se pode identificar o proêmio (parágrafos 1-5), a demonstração de inocência (parágrafos 6-21), o argumento

3 Os Cantos Cíprios de Estasino de Chipre datam do século VIII a.C.

4 Essa história se passa no seguinte contexto: quando os gregos foram à Ilha de Ítaca à procura de Odisseu na missão de convocá-lo à guerra movida contra os troianos, Odisseu, temendo não ver seu filho crescer, fingiu-se incapacitado pela insanidade. Odisseu quase foi bem-sucedido no seu intuito de enganar seus concidadãos e livrar-se da expedição. Contudo, Palamedes, desconfiado da loucura do herói, colocou Telêmaco, o pequeno filho de Odisseu, na frente de um arado na esperança que o pai abandonasse seu disfarce e fosse a socorro do menino, que estava prestes a ser pisoteado. Desse encontro teria surgido o desafeto de Odisseu em relação a Palamedes.

5 Prova disso é que Palamedes não é citado na Íliada e tampouco na Odisseia de Homero.

6 Além dos Cantos, parece que havia tragédias que evocavam o mito de Palamedes. Dentre elas uma de Ésquilo (fr. 181 e 182), outra de Sófocles (fr. 478-481) e uma terceira de Eurípides (fr.578 -590). Além das tragédias, ainda houve um discurso atribuído a Alcidamas, conhecido aluno de Górgias, que tematizava o mito de Palamedes. Essa multiplicidade de fontes nos autoriza a supor que a Atenas do século V conhecia razoavelmente bem o mito de Palamedes.

7 Por exemplo, existem semelhanças com as Tetralogias de Antifonte. 
do adversário (parágrafos 22-26), a contra acusação (parágrafos 27), o apelo aos juízes (parágrafos 28-36) e a recapitulação e encerramento (parágrafo 37 ) $^{8}$.

A análise de texto proposta neste artigo tem como objetivo, além de compreender o texto gorgiano, promover uma leitura do mesmo que ilumine os principais aspectos da Apologia de Palamedes à luz da Apologia de Sócrates de Platão. Ambas as defesas assemelham-se em diversos pontos. Desse modo, vincular os respectivos textos potencializa o entendimento das hipóteses acerca das relações entre elas ${ }^{9}$.

Palamedes inaugura seu discurso observando a questão da morte, visto que, se condenado por traição, seria punido com a pena capital. O início da defesa de Palamedes envolve o leitor e o interlocutor dramático (o jurado) em uma reflexão a respeito da honra e da condição humana. A discussão, segundo o réu, não parece ser se ele deve ou não deve morrer, pois por natureza todos estão fadados à morte. O verdadeiro debate é: Palamedes merece morrer honrado ou desonrado? Morrerá como um traidor da pátria e de si mesmo ou como um benfeitor, amigo da cidade e reconhecido inventor? Desse modo, o questionamento revela-se ser sobre o valor relativo da morte em relação à honra e à desonra, à justiça e à injustiça. É sobre esses pilares que Palamedes inicia sua defesa ${ }^{10}$.

Palamedes, assim como Sócrates ${ }^{11}$, lembra aos jurados que a morte é um evento comum e inescapável a todos os seres humanos. É interessante observar que Palamedes retira do âmbito humano um suposto poder atribuído às punições capitais. Ele o faz constatando que nem a acusação, tampouco a defesa, possuem poder real de decisão em relação à morte, por esta ser condição necessária da natureza humana. Assim sendo, Palamedes inaugura sua defesa movendo certos pressupostos e reorganizando à sua maneira a natureza daquele evento. Ele reconfigura, mesmo que sutilmente, as regras do jogo forense, apontando para o fato de que a situação na qual se encontra não se resume à condenação à morte enquanto punição, mas à justiça de sua vida e injusti-

8 Cf. Sub, Unstersteiner 1949, p. $112-113$.

9 Cf. Was the Apology a parody?

10 Górgias, Apologia de Palamedes, parágrafo 1.

11 Pode -se notar que, assim como Palamedes, Sócrates aponta para o fato de que a morte é um evento comum a todos os seres humanos e que a vida não deve ser vivida com o objetivo de evitar a morte a qualquer custo, mas, antes disso, com a finalidade de melhorar a alma tendo em vista a virtude e a justiça. 
ça das acusações imputadas a ele. Assim como Sócrates, ele coloca em questão o valor da morte comparado com o valor da virtude, no caso de Sócrates, e da honra, no caso de Palamedes, e ambos asseguram que a morte é preferível à privação das mesmas ${ }^{12}$.

No segundo parágrafo de Palamedes ${ }^{13}$ de Górgias, é interessante observar que o réu reconhece que a extensão do poder que possui limita-se à escolha de permanecer justo. Em oposição, o seu jurado tem o poder de decidir seu destino. Outro elemento interessante que aparece nesse contexto é a presença das dualidades ${ }^{14}$ que, por sua vez, são maneirismos comumente conhecidos e abundantes nos textos de Górgias ${ }^{15}$. O júri de Palamedes possui poder sobre a violência que pode ser cometida contra ele, que na sua expressão máxima, seria a morte. Por outro lado, Palamedes parece ser a autoridade única da justiça de suas palavras e ações. Porém, na mesma medida em que a morte é apresentada no texto como uma violência, ela não é uma violência que deve ser evitada a qualquer custo, vide o valor relativo dela em relação à honra. Isso se dá no seguinte sentido: se condenar alguém à morte é um poder violento que o estado, representado pelo jurado, pode cometer contra um homem, esse homem, se inocente, possui um poder maior ainda, que é a permanência na justiça e na virtude. A morte

12 Palamedes, no parágrafo 35 e Sócrates, nas passagens 28b-s 38d 39b afirmam que a morte é preferível à desonra.

13 Quando digo apenas Palamedes de Górgias refiro-me a Apologia de Palamedes, de Górgias, quando digo apenas Apologia, refiro-me a Apologia de Sócrates de Platão.

14 No fragmento analisado a seguir, a questão é apresentada como dúplice: "Sendo dúplice a questão, tendes toda a autoridade sobre uma, eu, sobre a outra: no que diz respeito à justiça, eu; quanto à violência, vós. Se quiserdes, podereis me matar facilmente, pois isso está em vosso poder, e nada posso fazer a respeito". (Górgias, Apologia de Palamedes, parágrafo 2).

15 No Elogio de Helena pode-se ver muito bem essa questão. Por exemplo, no primeiro parágrafo do Elogio já podemos observar uma série de dualismos. Cf. Elogio de Helena, parágrafo 1. Também, o próprio “objeto" do texto contém essa característica. É interessante notar que a lenda de Helena é perpassada pela dualidade o tempo inteiro. Ela é filha de Leda, Zeus e Tíndaro. Trata-se de uma sobreposição de dois pais: Leda pôs dois ovos, para ter quatro filhos. Do ovo fecundado por Tíndaro, o rei mortal, nasceram Pólux e Clitemnestra. Do ovo fecundado por Zeus, senhor do Olimpo, nasceram Helena e Castor. Helena, sendo uma, de certa forma reúne ou atrai o múltiplo, por exemplo: "inflamou a muitos com muitos desejos" e "com seu corpo reuniu muitos corpos". Os aspectos duplos de Helena de fato são vários: ela e seus irmãos nasceram de dois ovos, ela tem dupla nacionalidade, dupla fidelidade, dois maridos, e dois pais, um mortal e o outro imortal. Helena é duas também se consideramos a lenda de que a verdadeira Helena permaneceu no Egito durante os dez anos da guerra, e a que seguiu para Tróia com Páris foi, na realidade, sua imagem. 
é preferível frente ao abandono dos valores morais e manter-se fiel a esses valores confere aos réus em questão um tipo de poder especial.

Pela perspectiva proposta, a superação da morte através da justiça carregaria uma potência maior na medida em que fosse evidenciada. Ou seja, parte importante do bom funcionamento de defesa constitui em desacreditar ou simplesmente fazer-se desvelar a intenção e os objetivos do acusador responsável pelo processo, que no caso seria Odisseu. E é exatamente por esse caminho que Palamedes de Górgias seguirá ${ }^{16}$. A abordagem escolhida consiste, mesmo que não diretamente, na célebre polaridade entre doxa e aletheia. Dessa forma, dentro do texto do próprio sofista, nos é apresentada uma questão de cunho filosófico, que é a temática da disputa entre opinião e verdade. É interessante observar em relação à outra obra de Górgias, o Elogio de Helena. Nos parágrafos 8-14, Górgias também sugere que, apesar de o incontestável poder do discurso, a opinião parece ser algo facilmente distorcido e manipulável pelo discurso persuasivo da retórica. Com isso em mente, ao contrário da caricatura que Platão faz de Górgias e dos sofistas em geral, Górgias parece plenamente consciente da debilidade e instabilidade da opinião ${ }^{17}$. O que nos lembra do cuidado que devemos ter com as notícias que temos do sofista que nos chegaram através de Platão.

A Apologia de Palamedes parece ser um texto sustentado principalmente pelo argumento retórico de probabilidade (eikos) e também na construção do caráter do réu (êthopoiia). Ou seja, parte da estratégia retórica de Palamedes é evidenciar a impro-

16 Cf. Górgias, Apologia de Palamedes, parágrafo 3.

17 Cf. (1) A boa ordem da cidade [é] a coragem [dos seus cidadãos], a do corpo, a beleza, a da alma, a sabedoria, a da ação, a excelência, e a do discurso, a verdade. O contrário dessas coisas [é] a desordem. Em relação, pois, a um homem e a uma mulher, a um discurso e a uma ação, a uma cidade e a um negócio de Estado, é necessário tanto honrar pelo elogio público o que merece o elogio público quanto infligir repreensão ao que é indigno. Igualmente, pois, é erro e ignorância tanto reprovar as coisas louváveis quanto louvar as coisas criticáveis. (Elogio de Helena, 1). Górgias, Elogio de Helena. Tradução Aldo Dinnuci.

Neste primeiro momento do texto, Górgias nos apresenta a relação entre a cidade, o corpo, a alma, a ação e o discurso com o que ele chama de "boa ordem" de cada um desses elementos. Se a boa ordem não se apresenta, o que se apresenta, para Górgias, é a desordem. É interessante notar que logo neste momento de abertura do texto, Górgias assume algo que será muito importante mais adiante para este estudo, que é um compromisso com a verdade. O discurso para o sofista já está vinculado com uma ideia de verdade claramente expressa. O que veremos adiante será em que sentido Górgias relaciona a noção de verdade e mentira com o discurso e suas potências. 
babilidade de ele ter cometido o crime de que foi acusado ${ }^{18}$ devido à falta de motivo e possibilidades. É interessante perceber que Palamedes, não possui prova empírica de não ser culpado pela acusação que lhe foi imputada, ele não pode provar que não era um espião. O que ele pode oferecer é o testemunho de seus próprios concidadãos, a incompatibilidade de seu suposto crime com seu comportamento durante toda a vida, a falta de motivos, a utilidade que afirma ter para a cidade e os motivos duvidosos de seu acusador, aspectos que Sócrates também alegará em seu favor, na Apologia de Sócrates. Ademais, Palamedes, assim como Sócrates, utiliza-se da força das perguntas retóricas para realização de sua defesa ${ }^{19}$. Ao mesmo tempo, reivindica certa impotência discursiva, inabilidade retórica e afirma que se utilizará da palavra como um instrumento da verdade e alerta para o perigo em que se encontra ${ }^{20}$.

Um aspecto extremamente interessante que deve ser lembrad é a relação não tão obvia da capacidade da personagem em questão com a habilidade oratória e a técnica retórica, outra similaridade que parece haver entre Palamedes e Sócrates. Ambos os réus afirmam suas limitações em relação à habilidade oratória e, ao fazê-lo, também apontam suas debilidades discursivas como um possível elemento de fracasso de suas defesas. Assim, lembram, não só que, se forem bem-sucedidos o serão apenas pela verdade de suas palavras e, consequentemente, não pela beleza e persuasão de seus discursos tecnicamente preparados, como seria um discurso forense normativo. Ambos, ao mesmo tempo em que afirmam não possuir habilidade retórica, produzem discursos retoricamente ajustados.

A perplexidade de Sócrates e de Palamedes, assim como a afirmação de falta de habilidade retórica é colocada como "prova" de suas respectivas faltas de conhecimento de procedimentos de tribunal, o que, consequentemente, segundo o que foi intencionado, seria prova de suas vidas corretas. Ambos, ao aliarem a falta de habilidade retórica

18 Que no caso seria a traição dos gregos em favor dos troianos.

19 Segundo Queiroz e Mattoso, nota 6, p.178, as perguntas retóricas são de certa forma um instrumento para a representação de um diálogo dos personagens com eles próprios, que teria por objetivo construir uma espécie de elenco retórico.

20 "Mas, ao falar a esse respeito, por onde começar? O que dizer primeiro? A que ponto da defesa me voltar? De fato, uma acusação que não pode ser provada inspira evidente desconcerto, e, por esse desconcerto, necessariamente o discurso é bloqueado, a não ser que eu aprenda algo a partir da própria verdade e da presente necessidade, perante mestres mais perigosos que talentosos”. (Górgias, Apologia de Palamedes, parágrafo 4). 
com a verdade de suas palavras e com certa ingenuidade ou ignorância dos procedimentos forenses atribuem quase que forçosamente a habilidade retórica à afinidade aos procedimentos em tribunal, associando-os com o perigo que estão expostos pelas suas respectivas condições. E ambos o fazem utilizando-se magistralmente de estratégias retóricas. Palamedes afirma que tem plena consciência de ser inocente. Porém, como carece de provas “concretas”, utiliza-se de outras estratégias em sua defesa ${ }^{21}$.

Palamedes tenta mostrar que agir como um espião não seria proveitoso para ele de nenhuma maneira, assim como Sócrates afirma que, ao corromper os jovens que o circundavam, estaria na verdade causando mal a si mesmo. Ou seja, corromper a juventude não seria vantajoso para o próprio Sócrates e assim, não há motivos para fazê-lo. Palamedes afirma não possuir os meios para ter cometido a traição. Além disso, lembra que tornar-se aliado dos troianos não lhe traria nenhum beneficio financeiro. De modo semelhante, Sócrates utiliza-se de sua pobreza para provar sua inocência. Sem recompensa financeira, ele não poderia ser acusado de ser um professor de virtude à moda sofistica. Ambos evocam suas ações passadas e suas vidas para provar a incoerência de seus supostos crimes.

Em adição a isso, Palamedes explicará seu plano de defesa, dividindo-o em dois ${ }^{22}$. Em primeiro lugar Palamedes buscará evidenciar sua falta de meios para cometer a suposta traição. Ou seja, ele utilizará uma conhecida estratégia retórica, os argumentos de probabilidade. Essa estratégia consiste em buscar evidências da improbabilidade de se cometer determinada ação. Normalmente, essa estratégia é utilizada quando há uma impossibilidade de se provar diretamente a inocência do acusado, ou quando provas empíricas desse tipo não estão na natureza do crime cometido. Por exemplo: quando se trata de um homicídio, seria possível apresentar como prova o corpo da vítima, a

21 Que, portanto, o acusador me acusa sem claramente conhecer os fatos, sei claramente, pois tenho a clara consciência de que não fiz nada de tal tipo, nem vejo como alguém poderia saber como existente o que não aconteceu. Mas, se ele fez a acusação por supor que as coisas se passaram assim, que não fala a verdade vos mostrarei de dois modos. De fato, nem querendo eu pude nem podendo eu quis pôr as mãos em tais manobras. (Górgias, Apologia de Palamedes, parágrafo 5).

22 Pode-se verificar aqui mais uma amostra da dualidade abundantemente presente nos textos de Górgias. 
arma utilizada e assim vincular a posse da arma do acusado com o tipo de ferimento da vítima, etc ${ }^{23}$.

Palamedes busca reforçar nesse primeiro momento, mais do que a incompatibilidade de sua personalidade com o suposto crime de traição, a impossibilidade empírica para a realização do crime. Ele tenta razoar com seu jurado quando explica que, para que a traição tivesse de fato ocorrido, seria necessário que antes algo tivesse sido arranjado. Ou seja, seria preciso que Palamedes tivesse se encontrado e conversado com os troianos, ou com algum mensageiro troiano. Sem o mensageiro, o encontro teria sido impossível e, através da inexistência de tal mensageiro, Palamedes busca provar que tal encontro não teria existido, e assim, tampouco a traição ${ }^{24}$.

A partir da dinâmica no encontro, das conversas necessárias e do mensageiro, Palamedes apresenta outro fator de impossibilidade: a língua. Palamedes lembra que, sendo grego, teria dificuldade de se comunicar com um troiano. Para que isso acontecesse seria necessário um tradutor e este não apareceu como testemunha de seu crime no tribunal, pois não existe, já que a traição nunca ocorreu. Desse modo, Palamedes vai lentamente destruindo o arcabouço da acusação de Ulisses ${ }^{25}$. Através das perguntas retóricas, Palamedes permanece expondo a dificuldade que ele teria

23 "Abordarei primeiro esse argumento, de como sou incapaz de fazer tal coisa. De fato, seria preciso haver primeiro o início da traição, e o início seria uma conversa, pois antes de ações futuras é força que haja conversas primeiro. Mas como haveria conversa sem que houvesse algum encontro? $\mathrm{E}$ de que modo haveria um encontro sem que me enviasse alguém ou sem que de minha parte alguém fosse até ele? Nem uma mensagem em tabuinhas chega sem um portador". (Górgias, Apologia de Palamedes, parágrafo 6).

24 "Mas aceitemos que isso possa ter acontecido por meio de uma conversa. E então, de algum modo eu o encontro e ele me encontra. Quem encontra quem? Um heleno com um bárbaro. Como ouvir ou falar? Acaso a sós? Mas ignoramos a língua um do outro. Com um intérprete, então? Mas haveria uma terceira testemunha do que deveria permanecer oculto. (8) Que isso tenha acontecido então, embora não tenha. Seria preciso, depois disso, dar a receber uma garantia. Qual seria então a garantia? Um juramento? E quem estaria disposto a confiar em mim, um traidor? Reféns, então? Quem? Como tal eu teria dado meu irmão (pois não teria outro) e o bárbaro, um de seus filhos pois essa seria a máxima garantia dele para comigo e de mim para com ele. Mas, tivesse isso acontecido, seria evidente a todos vós". (Górgias, Apologia de Palamedes, parágrafo 8).

25 Segundo, Queiroz e Mattoso “Além de a presença de uma testemunha despercebida se constituir num argumento a mais de Górgias na alegação da inexistência dos fatos da acusação, pode haver aqui também um subtexto, um artifício metalinguístico gorgiânico, segundo o qual, em se tratando de um processo de eisaggelía, como supomos, uma testemunha descaracterizaria o caráter brutal e arbitrário desse tipo de ação, em que o réu não dispõe de fatos concretos em sua defesa, restando-lhe apenas o lógos persuasivo para safar-se. Desse modo, “o que precisa ser ocultado", a todo custo, é, além dos 
de cometer o crime hediondo e a falta de probabilidade de tê-lo cometido devido à multiplicidade de obstáculos que ele encontraria no caminho.

Além da dificuldade das conversas pelas divergências da língua e da falta de um mensageiro ou tradutor, Palamedes sugere a improbabilidade de uma aliança entre um grego e um troiano, a falta de confiança nas relações, a dificuldade de, mesmo combinada a traição, realizar o transporte do pagamento (motivo possível), a dificuldade de ter realizado a traição, transportado dinheiro ou arranjado encontros sem que houvesse alguma testemunha, mensageiro, guarda, etc ${ }^{26}$.

Através desses argumentos ele busca evidenciar que Odisseu não possui um caso forte contra ele. Não possui nada além da sua opinião que, como já vimos, é facilmente distorcida, manipulada e frágil. De acordo com Mattoso e Queiroz, essa investigação é, na verdade, uma “concessão retórica” no seguinte sentido: a investigação implementada por Palamedes parece ser um auxílio falso que expõe a fraqueza dos argumentos de Odisseu. De modo semelhante, Sócrates, na Apologia utiliza-se dessa estratégia ${ }^{27}$ quando se propõe a investigar a origem primeira de suas acusações. Nesse primeiro momento da arguição, portanto, Palamedes concentra-se em, acima de tudo, mostrar a improbabilidade de a traição ter sido cometida por motivos práticos e materiais ${ }^{28}$.

No desenvolvimento da leitura, pode-se observar que o personagem de Palamedes adota uma postura clássica da retórica aduladora. Ele reconhece seus jurados como os únicos homens livres de seu convívio que poderiam tê-lo auxiliado na suposta traição, envolve-os na própria história (assim como Sócrates faz na Apologia). Palamedes

fatos pretensamente criminosos, a própria presença de uma testemunha, inviabilizadora de uma peça retórico-forense de eisaggelía, em seu formato mais radical". Pag. 180 nota 16.

26 "Alguém dirá que o dinheiro foi usado como garantia, ele dando e eu recebendo. Teria sido pouco, então? Mas não é provável receber pouco dinheiro em troca de grandes serviços. Muito dinheiro, então? Qual seria o transporte? Como uma só pessoa o fez? Ou foram muitas? Fossem muitos os carregadores, muitas seriam as testemunhas do conluio; fosse um apenas, não haveria muito a carregar. (09) O transporte foi durante o dia ou à noite? Mas são muitas e contíguas as sentinelas, por entre as quais não se pode passar despercebido. Durante o dia, então? Mas, efetivamente, a luz é hostil a tais ações. Mas que seja! Fui até ele receber ou ele trouxe até mim? Ambas as situações são impraticáveis, de fato. Em posse do dinheiro, como o escondi dos íntimos e dos estranhos? Onde o teria posto? Como o vigiaria? Se o usasse, me revelaria; se não o usasse, de que me serviria?" (Górgias, Apologia de Palamedes, parágrafo 10).

27 Cf. Apologia de Sócrates, 18a8.

28 Cf. Górgias, Apologia de Palamedes, parágrafos 11-12. 
convida-os a participar e convida-os a expô-1o ${ }^{29}$. Desse modo, ele consegue ressaltar a fragilidade da acusação e ao mesmo tempo ele bajula seu jurado quando fala, por exemplo, que seriam precisos “inimigos mais poderosos", o que, por sua vez, “é impossível”. Na medida em que Palamedes não apenas defende o seu caráter e a virtude de sua vida, mas recorre a uma retórica de adulação, fica claro a intenção Gorgiana de revelar a astúcia de uma retórica que não se reconhece abertamente enquanto tal mas tem conhecimento de seu recurso técnico.

Até agora pudemos observar Palamedes expondo as impossibilidades práticas para a realização do crime. O personagem Palemades esteve dedicado a expor as evidências que justifiquem que as condições externas a sua própria vontade eram desfavoráveis à suposta traição. Porém, finalizada essa exposição, ele inaugura análise não só da impossibilidade da traição, mas falta de desejo de agir de forma desonrosa. Ele não só não teve o poder de agir, como não teve o desejo ${ }^{30}$. Ou seja, Palamedes defende-se alegando que, não só não pode ter cometido a traição por falta de possibilidades empíricas como não desejou em nenhum momento cometer o crime pelo qual foi acusado e que a ação criminosa seria incoerente com o testemunho de sua vida inteira ${ }^{31}$.

29 Queiroz e Mattoso, p180. "Interpelação puramente retórica à multidão: não era prevista legalmente a participação nem de juízes nem da audiência como testemunhas no direito ático do século V/ IV, época em que Górgias parece situar esse modelo de defesa contra uma eisaggleia. Sócrates faz precisamente o mesmo na Apologia (19d1-d6), acrescendo à fórmula retórica uma nota de desprezo pelo instituto democrático do testemunho: seu procedimento aqui é idêntico na forma, mas tem fins diversos, como vimos na introdução."

30 "Examinai em comum também isto: por que me conviria desejar tal coisa, caso tivesse, mais do que todos, a possibilidade? Ninguém deseja gratuitamente correr os maiores riscos ou ser considerado o pior pela maior perfídia. Por que motivo, então? E insisto nesse ponto. Acaso para exercer poder absoluto? Sobre vós ou sobre os bárbaros? Sobre vós, tão numerosos e tão valorosos, é impossível; vós, que tendes a vosso favor toda a grandeza, a virtude dos antepassados, imensa fortuna, feitos heroicos, força de espírito, o domínio das cidades. 14 Sobre os bárbaros, então? Mas quem me entregaria esse poder? Com que forças eu, um heleno, dominaria os bárbaros, sendo um, e eles, muitos? Por meio da persuasão ou da violência? Pois nem eles se deixariam persuadir nem eu poderia usar de violência. Mas talvez eles me concedessem de mútuo acordo, como pagamento da traição? Mas seria realmente muita estupidez confiar em tais acordos e aceitá-los: quem escolheria a escravidão em vez da soberania, o pior em vez do melhor?" (Górgias, Apologia de Palamedes, parágrafo 13-14).

31 "Alguém poderia dizer que pus as mãos nisso por amor ao dinheiro e à riqueza. Mas possuo dinheiro suficiente e não preciso de muito. Quem precisa de muito são os que muito gastam, não os que têm domínio sobre os prazeres físicos, mas sim os que são escravos desses prazeres e que procuram obter honras mediante a riqueza e a suntuosidade. Nada disso é de meu feitio. E de que falo a verdade, darei como testemunho fidedigno minha vida passada. Desse testemunho sois testemunha, pois conviveis comigo, e portanto, sabeis bem disso. E certamente não seria por honra que um homem 
Essa questão também aparece de forma análoga na Apologia de Sócrates na discussão de Sócrates de Meleto, com certa ironia. O filósofo afirma que não só não quer corromper a juventude, como também não pode fazê-lo, pois, como exposto pelo filósofo, seria preciso muitos homens para corromper a juventude já que, segundo Meleto, todos os homens da cidade educariam e fariam bem aos jovens enquanto que apenas Sócrates os corromperia.

Ambos, Palamedes e Sócrates, utilizam-se de suas ações passadas e da notoriedade de suas personalidades para afirmar que não possuem um caráter que lhes levaria a cometer os crimes dos quais são acusados. Na tentativa de darem suas próprias vidas como provas de sua boa conduta, ambos os réus escolhem como a testemunha de suas ações retas seus próprios concidadãos, representados no tribunal pelo próprio jurado responsável pelo veredito de seus julgamentos. Palamedes afirma só estar no tribunal, pois conquistou o desafeto de Odisseu, enquanto que os desafetos conquistados por Sócrates compõem um conjunto mais numeroso que poderia incluir políticos, sofistas e poetas. Ambos utilizam-se da instituição democrática do testemunho de forma pouco usual, talvez irônica, mas certamente extraordinária e não convocam testemunhas que poderiam factualmente ajudá-los em suas defesas.

Palamedes, assim como Sócrates, atualiza-se do recurso discursivo do interlocutor imaginário. Sua investigação acerca do dinheiro, na verdade, é uma investigação sobre as necessidades e as paixões humanas. Palamedes se isenta de culpa na medida em que afirma não ser suscetível a tais paixões. Tanto Sócrates quanto Palamedes apontam para a virtude de suas ações passadas. Palamedes afirma a incorruptibilidade de suas ações e sua fidelidade à honra.

Deve-se observar ainda que o Palamedes de Górgias investiga durante o desenvolvimento de seu argumento de probabilidade possíveis motivos vinculados às paixões e as necessidades, que poderiam levar alguém ao crime de traição ${ }^{32}$. Ou seja, trata-se de

medianamente sensato poria as mãos em tais manobras, pois é da excelência e não da covardia que nascem as honras. Como poderia haver honra para um homem que trai a Hélade? Além disso, honra não me falta. De fato, fui honrado pelos mais honrados em razão do que há de mais honroso, por vós, em razão da sabedoria”. (Górgias, Apologia de Palamedes, parágrafo15-16).

32 Górgias também empreende uma análise semelhante no Elogio de Helena. Cf. Elogio de Helena, parágrafo 6. 
uma análise a respeito da existência de um motivo por trás da traição. Através dessa investigação Palamedes pretende evidenciar que, além de não possuir condições práticas para a traição, ele tampouco teve uma motivação para realizá-la.

Desse ponto de vista, aqueles que se submeteriam às paixões seriam sob certo aspecto mais frágeis e com menos convicção moral, enquanto que oferecer resistência a essas paixões seria uma forma de força e libertação. Desse modo, essa libertação apologética das paixões seria, se analisada em comparação com o que pode ser inferido da Apologia de Sócrates, uma forma de atingir um estado mais próximo das divindades. $\mathrm{Na}$ medida em que houvesse essa ascese dos desejos do corpo, seria possível uma aproximação da elevação moral e, por consequência, uma expansão da possibilidade de acesso ao conhecimento ${ }^{33}$.

A abordagem negativa, que tanto Palamedes quanto Sócrates parecem ter, atribui quase que exclusivamente à presença do dinheiro certo caráter corrupto. O dinheiro, para Palamedes, é representado como uma ferramenta útil na conquista (aparentemente indevida) de cargos na política pública e na conquista de status social. Palamedes afirma seu compromisso irrevogável com a honra e rejeita uma relação corrupta com o dinheiro e assim constrói um elogio de suas ações e seu caráter ${ }^{34}$.

É profícuo observar a seguinte construção retórica: se Palamedes foi benfeitor, promovendo o bem-estar coletivo e se tem por testemunhas suas ações em vida, não poderia ser traidor, pois este se opõe necessariamente à justiça, à lei, aos deuses e aos homens. Essa incompatibilidade quase ontológica entre a figura do traidor e a do bom cidadão ocupado com o bem coletivo busca interditar, quase de maneira lógica (o que seria no caso uma falsa indução) a possibilidade de um homem em um momento ser sido um amigo da cidade e em outro um traidor.

Novamente Palamedes evoca a ideia também utilizada por Sócrates de que ninguém deseja sofrer um mal. Quando ele o faz, novamente a Apologia de Palamedes assemelha-se consideravelmente com a passagem da Apologia de Sócrates, onde este afirma que

33 Esse pensamento é atribuído a Sócrates em diálogos tais como o Banquete e a própria Apologia de Sócrates.

34 Górgias, Apologia de Palamedes, parágrafo 17-18. 
não deseja cometer mal aos seus amigos e aqueles que o frequentam, pois isso seria na verdade cometer um mal contra si mesmo ${ }^{35}$.

Palamedes rejeita firmemente a suposta traição e busca evidenciar que esta seria extremamente dolorosa para ele, incoerente com suas ações e seu passado, e que a vida privada da relação com sua cidade, seus concidadãos e sua cultura seria terrível. Dessa maneira, Palamedes afirma que não causaria esse sofrimento a si próprio. Palamedes é um personagem que dirige suas ações e afirma sua resistência diante das necessidades e paixões que vulgarmente influenciariam homens mais fracos. Paralelamente, se a Helena de Górgias é inocente, pois é atravessada a todo o momento por forças exteriores e mais fortes que ela ${ }^{36}$, Palamedes é inocente por ser senhor

35 Resta verificar se agi fugindo de algum temor, sofrimento ou perigo. Ninguém, porém, poderia dizer que isso se aplica a mim. Por dois motivos todos fazem tudo: para perseguir um lucro ou evitar uma perda. Fora isso, quanto mal é praticado é obra da loucura. O quanto prejudicaria a mim mesmo ao fazer isso é bem evidente, pois, ao trair a Hélade, trairia a mim mesmo, os filhos, amigos, a honra dos antepassados, os altares paternos, os sepulcros e a pátria, a maior da Hélade. O que para todos está acima de tudo, eu teria posto em mãos inimigas. Examinai também isto: como não me seria intolerável a vida depois de praticar tais ações? Para onde me voltaria? Acaso para a Hélade? Para ser punido pelos injustiçados? Quem, dentre os que sofreram males terríveis, me pouparia? Permaneceria então entre os bárbaros? Desprezando toda grandeza, provado da mais bela honra, vivendo na mais vergonhosa infâmia, esquecendo -me dos sofrimentos da vida passada, sofridos em razão da excelência? E isso por minha própria culpa, o que é o mais vergonhoso para um homem, cair em desgraça por sua própria causa! (Górgias, Apologia de Palamedes, parágrafo 19-20).

36 No parágrafo seis do Elogio de Helena, Górgias lista os possíveis motivos pelos quais Helena teria ido a Tróia para, posteriormente, analisá-los separadamente. As palavras que nos induzem à ideia de que Helena não teve responsabilidade ou até mesmo escolha nesse movimento são muitas. (Cassin, 1990, p. 3054 -306) Górgias fala, por exemplo, de destino, necessidade, força, sedução, captura, desejo divino. Górgias cria imagens, com seu discurso, de uma Helena que é arrastada a todo momento por forças que são exteriores a ela mesma. O primeiro motivo analisado por Górgias imediatamente redime Helena de qualquer participação voluntária no que aconteceu em sua vida e na vida da Grécia. Pois, se Helena fez o que fez por "anseios da fortuna e pelas resoluções dos deuses”, então ela é inocente. Górgias constrói um argumento ressaltando as relações de força (novamente trazendo essa imagem da força), onde o fraco, por natureza, é submetido pelo mais forte. Os deuses, sendo mais fortes que os homens e seus desígnios, os submetem à vontade divina. Assim, se Helena foi para Tróia pelo motivo citado, sendo humana e consequentemente, mais fraca que os deuses, ela é inocente. No parágrafo sete Górgias apresenta a próxima opção da sua lista de razões pelas quais Helena foi para Tróia: Helena foi forçada pelos homens (ou por um homem). Nesse caso, se Helena foi “arrebatada à força, ilegalmente submetida e injustamente tratada com insolência", ela também é inocente. Novamente obrigada por uma força exterior e superior a ela, a força do(s) homem(ns), ela é certamente vítima das circunstâncias, tendo sofrido injustiça e sendo digna de piedade. 
de si mesmo e resistir a tais forças. É nessa autarquia que Palamedes se aproxima de Sócrates e se distancia de Helena.

Seguindo a análise da defesa, pode-se observar que Palamedes passa efetivamente para a última etapa esperada de um discurso de defesa em um tribunal. Palamedes introduz uma sequência de argumentos lógicos na tentativa de demonstrar que seu acusador não possui nenhuma fonte segura que justifique o processo contra ele ${ }^{37}$. Ele evidencia através de seu argumento que é impossível dar testemunha do que não ocorreu, visto que não ocorreu, enquanto que é forçoso dar do que ocorreu. Desse modo Palamedes expõe um problema lógico da acusação de Ulisses. De maneira semelhante, Sócrates expõe a fragilidade dos argumentos de Meleto. Na passagem 23d 24c Sócrates acusa Meleto de fingir-se importar com coisas que na verdade não o interessam ${ }^{38}$.

Pode-se observar que Palamedes, assim como Sócrates na Apologia, troca momentaneamente de lugar e emprega um interrogatório dedicado a seu acusador, na tentativa de expor suas reais motivações, fazer um retrato de caráter negativo e desvelar a falta de provas e argumentos de seus casos. Outra semelhança que não deve ser ignorada é que a fala de Palamedes ${ }^{39}$ assemelha muito à fala de Sócrates na Apologia na passagem (25e-26a).

37 Cf. Górgias, Apologia de Palamedes, parágrafos 22-23.

38 "Que, portanto, me acusas sem conhecimento dos fatos é manifesto. De resto, se não sabes, supões. E é assim, ó mais ousado de todos os homens, fiando-te na opinião, a matéria menos digna de confiança, sem saber a verdade, que tu ousas expor um homem à morte? Que tipo de ação sabes que ele praticou? Certamente que opinar a respeito de tudo é algo comum a todos e nisso tu não és nem um pouco mais sábio do que os outros. Não se deve confiar no que se supõe, mas no que se sabe, nem considerar a opinião mais digna de confiança do que a verdade, mas, ao contrario, a verdade mais do que a opinião (24). Pelo que foi dito, acusaste-me das duas características mais opostas: de sabedoria e de loucura, que não podem habitar o mesmo homem. Quando dizes que sou engenhoso, terrivelmente sagaz e cheio de expedientes, tu me acusas de sabedoria, mas quando dizes que traí a Hélade, de loucura. Pois é loucura pôr as mãos em ações irrealizáveis, intoleráveis, vergonhosas, com as quais se prejudica os amigos, mas se beneficia os inimigos, e que tornam sua vida algo frágil e infame. Como, então, deve-se confiar em tal homem, um homem que, suando os mesmos argumentos perante os mesmos homens acerca dos mesmos fatos, afirma as coisas mais opostas”? (Górgias, Apologia de Palamedes, parágrafo 25).

39 "Gostaria de ouvir de ti se julgas sábios os homens tolos ou os sensatos, pois se são os tolos, é novo o argumento, mas não verdadeiro; se, porém, são os sensatos, sem duvida não convém aos que têm bom senso cometer os maiores erros e preferir os males aos bens que estão a seu alcance. Portan- 
Nesse sentido, tanto Sócrates quanto Palamedes afirmam que a natureza do suposto crime não pode ser aproximada de uma intencionalidade da parte deles e assim, o erro deliberado seria impossível. Ambos também afirmam que, comprovada sua sabedoria, seria impossível que tivessem cometido os crimes dos quais foram acusados, pois nenhum homem sábio agiria de maneira perversa. Mais uma vez aqui se pode observar a oposição entre verdade e opinião. Górgias, ao contrário do que se normalmente concebe do pensamento sofistico, certamente separa alguma noção de verdade de alguma noção de opinião.

Um mecanismo recorrente tanto no texto de Górgias quanto no texto de Platão é a transformação do acusador em caluniador. Essa dinâmica segue-se normalmente quando o acusador é exposto como incapaz de provar objetivamente, incluindo através de testemunhas, a culpa do acusado ${ }^{40}$. Desse modo, o réu empreende um processo de desmascaramento das intenções do acusador a fim de expor o que seria a verdadeira motivação; promover a calunia. Nesse caso, o próprio acusador agiria de maneira ilegal, arrastando ao tribunal, como disse o personagem Sócrates na Apologia, pessoas que não deveriam estar ali.

Pode-se verificar que Palamedes, assim como Sócrates ${ }^{41}$, lembra aos seus jurados sua utilidade para a cidade, ou seja, aponta para as benfeitorias que este realizou durante a sua vida. Palamedes defende seu irrevogável valor quando atribui os benefícios de suas invenções, não só à sua cidade e aos gregos, mas a toda a humanidade ${ }^{42}$. Ele reclama para si a autoria de muitas invenções úteis, de grande valia para toda a huma-

to, se sou sábio, não errei, mas, se errei, não sou sábio. Assim sendo, dos dois modos tu serias um mentiroso". (Górgias, Apologia de Palamedes, parágrafo 26).

40 "Em primeiro e segundo lugar, e principalmente, do início ao fim, em tudo, minha vida passada é irrepreensível, pura de qualquer culpa. Ninguém poderia me acusar de perfídia sem mentir perante vós. De fato, nem o próprio acusador apresentou qualquer prova do que disse. Desse modo, seu discurso tem a força e o peso de uma injuria infundada”. (Górgias, Apologia de Palamedes, parágrafo 29).

41 Cf. Apologia de Sócrates, 36d.

42 "Eu diria, e, ao dizer, não estaria mentindo nem poderia ser refutado, que sou não apenas irrepreensível como também um grande benfeitor para vós e para os helenos- e para todos os homens, os de agora e os futuros. Quem, pois, tornou a vida humana possível a partir do impossível e ordenada a partir da desordem, ao inventar táticas militares, essenciais à supremacia, as leis escritas, guardiãs do que é justo, o alfabeto, instrumento da memória, os pesos e as medidas, facilitadores das trocas comerciais, os números, guardiões da riqueza, os sinais de fogo, os mais poderosos e velozes mensageiros, o jogo de dados, como forma agradável de passar o tempo livre?”. (Górgias, Apologia de Palamedes, parágrafo 30). 
nidade, incluindo para os homens do futuro. Já Sócrates afirma uma benfeitoria não exatamente prática, mas espiritual. No sentido de manter a cidade atenta afirmando que é um moscardo para a cidade, acordando-a de sua letargia ${ }^{43}$ e no sentido de tentar persuadir seus concidadãos a ocuparem-se com o próprio desenvolvimento moral.

Sócrates usa sua pobreza e descaso com negócios pessoais ${ }^{44}$ como evidência de sua devoção e entrega ao bem-estar moral da cidade. Ele defende a utilidade de sua filosofia enquanto uma atividade que incita seus concidadãos a se inclinarem para o engrandecimento moral e para a sabedoria em detrimento, se necessário, do bem-estar corporal, da riqueza, do status e do poder político. Palamedes, por sua vez, sugere que, se ele se ocupa dessas atividades, seria incoerente também trair os gregos, pois existiria uma contradição quase lógica em alguém que se ocupou de coisas tão boas para todos, se engajar em algo tão perverso quanto uma traição ${ }^{45}$.

Tanto Sócrates quanto Palamedes evocam sua utilidade para a cidade e ilustram isso lembrando sua participação na vida militar da cidade. Ambos sentem a necessidade de justificar sua permanência na existência através dos serviços que podem oferecer à pólis. Tal fato nos permite perceber uma elevação de aspectos práticos relacionados aos serviços que os cidadãos enquanto indivíduos poderiam oferecer para o bem-estar comum. Ou seja, trata-se de uma civilização que valoriza aspectos coletivos em detrimento de aspectos particulares. Se por um lado Palamedes e Sócrates são acusados de crimes que os beneficiariam individualmente, suas defesas apelam para as suas ações devotadas ao bem da coletividade.

43 Cf. Apologia de Sócrates, 30 e.

44 Cf. Apologia de Sócrates, 36b-c, 30a-c.

45 "Para deixar claro que me dedico a tais feitos e dar prova de que me mantenho longe de ações infames e maléficas, pois se me dedico àqueles é impossível dedicar-me a estas. Não mereço, portanto, eu que em nada vos prejudiquei, ser eu mesmo prejudicado. (31) E nem mesmo por causa de outras ocupações mereço padecer qualquer mal, nem por parte dos mais jovens nem dos mais velhos, pois aos mais velhos não causo aflições e aos mais jovens não sou inútil. Aos afortunados não invejo, dos desafortunados me compadeço; nem menosprezo a pobreza, nem estimo mais a riqueza do que a virtude, e sim a virtude mais do que a riqueza. Não sou inútil nas assembleias, nem indolente nos combates; executo o que foi ordenado e obedeço aos superiores. Não é de meu feitio o autoelogio, mas a presente ocasião me obriga, uma vez acusado, a defender-me de todas as formas". (Górgias, Apologia de Palamedes, parágrafo 32). 
Tendo fundamentado sua vida no terreno das ações virtuosas destinadas ao bem-estar público, Palamedes alega uma incoerência ou uma contradição ética entre o Palamedes amigo e benfeitor de sua cidade, tal como ele proclama ser, e o Palamedes traidor, tal como afirma seu acusador. Palamedes tenta produzir um argumento que sustentaria certa incompatibilidade entre um mesmo homem que em determinado momento age positivamente em relação a sua cidade e em outro momento negativamente. Essa incoerência apontada pelo réu é forçada no sentido de aparentar ser uma impossibilidade.

Segundo Queiroz e Mattoso, na perspectiva gorgiana, “a habituação de querer numa direção parece capaz de interditar o poder agir em outro sentido. Na perspectiva socrática, não basta a habituação, é preciso cognição: o que basta é o saber do bem”. Dessa forma, a compreensão do conceito de "bem" mostra-se como diferenciada entre Palamedes e Sócrates, e, em ultima instância, entre Górgias e Platão. Contudo, para além das diferenças imediatas, pode-se reconhecer uma semelhança no quesito da presença de uma "impossibilidade da contradição ética" entre os dois. Ambos parecem compartilhar de uma compreensão do pensamento e da ação humana que pressupõe que, para quem age de determinada maneira, ou, para quem sabe o que é o bem, é impossível agir de maneira oposta (caso essa fira os princípios do caráter), ou seja, é impossível que um homem bom se comporte de maneira perversa.

Deve-se lembrar que, nesse momento do texto ${ }^{46}$, ainda está empregado o argumento de probabilidade. Ou seja, seu objetivo permanece sendo demonstrar que Palamedes, de acordo com suas ações passadas, não poderia ter cometido o crime de traição, pois isso significaria uma incoerência comportamental que não pode ser provada. Palamedes, tendo sido útil, virtuoso e amigo de sua cidade no passado, não seria, provavelmente, vilão e traidor da mesma posteriormente. É nesse encadeamento quase lógico que se desvela o argumento de probabilidade de Palamedes.

Já no caso de Sócrates, o uso do argumento de probabilidade não é tão presente. O filósofo, apesar de afirmar sua utilidade para o bem coletivo, o faz de maneiras distintas. Por um lado, Sócrates lembra seu júri de sua admirável conduta guerreira, porém por outro, ele se coloca indiscutivelmente vinculado com um entendimento próprio de 
justiça e virtude que é independente do entendimento comum da cidade, e permanecerá agindo de acordo com essa fé pessoal, que, por sua vez, está indissociavelmente ligada a um demônio pessoal. O que simbolicamente corrobora uma das acusações computadas contra ele. Se Sócrates possui um demônio pessoal que dita exclusivamente para ele uma moral própria, então, por associação, não acredita nas divindades da cidade e na moral da cidade. Ao dispensar os mediadores das relações com as divindades do seu convívio por ele mesmo ter uma espécie de acesso direto e particular com uma divindade não nomeada, Sócrates torna-se livre para utilizar a estrutura oracular religiosa a sua maneira. Essa subversão e emancipação dos registros tradicionais da relação com as divindades, a moral e por consequência, o estado, marginalizam a figura de Sócrates e o tornam, sob muitos aspectos, perigoso ao status quo coletivo.

Palamedes, assim como Sócrates na Apologia, se recusa a suplicar por sua vida e pedir por piedade. Ambos também rejeitam trazer seus amigos e familiares para pedirem pela vida deles ${ }^{47}$. Tanto Palamedes quanto Sócrates acreditam que as súplicas e as bajulações são um meio retórico eficiente, porém desonroso, e por isso repudiam-no. Os dois réus sustentam a hipótese de convencerem seus juízes baseando seus argumentos da racionalidade e na verdade. Ambos declaram-se fiéis ao que acreditam ser justo e honroso e recusam-se a agir de maneira injusta, mesmo colocando suas próprias vidas em risco ${ }^{48}$.

O paragrafo 33 marca o início do que na retórica clássica se chama peroratio que se estende até o parágrafo 37 . A peroratio nesse momento da defesa inclui uma pequena ethopoiia, ou seja, um retrato de caráter dos juízes. Palamedes já construiu um retrato de caráter de Odisseu, assim como um de si mesmo. Na construção de caráter dos juízes, Palamedes afirma que, ao contrário das multidões incultas, os juízes não teriam necessidade de ouvir súplicas e bajulações justamente por serem superiores e não

$47 \mathrm{Na}$ Apologia de Sócrates, Sócrates, de forma semelhante a Palamedes, diz que não chamaria seus amigos e familiares, esposa e filhos para chorarem e suplicarem por sua vida, pois esse comportamento seria indigno e incoerente com seu caráter. Cf. Apologia de Sócrates, passagem 34e.

48 "Resta-me, diante de vós, o discurso a vosso respeito, com o que porei fim à defesa. A lamentação, as preces e a intercessão dos amigos são úteis quando se tem a multidão por juiz. Mas, a vós, que sois os primeiros dentre os helenos, e reconhecidos como tal, é preciso que vos convença não com a ajuda dos amigos, nem com preces ou lamentações, mas sim com a máxima evidência do que é justo, pois é expondo a verdade, sem recorrer ao engano, que devo ser absolvido dessa acusação". (Górgias, Apologia de Palamedes, parágrafo 33). 
influenciáveis por esse tipo de artifício. Evidentemente, Palamedes está, através dessa constatação, buscando converter de certa forma a percepção dos juízes para que esses compactuem com o seu posicionamento no tribunal. Ao articular a ideia de superioridade com a rejeição às bajulações e súplicas, Palamedes tenta persuadir os jurados a confirmarem seu ideal de comportamento justo. De maneira semelhante, Sócrates, na passagem 35c, afirma que o júri deve se comportar de maneira justa, prestando atenção apenas à verdade de suas palavras e ações e não a artifícios dramáticos. Assim, Palamedes e Sócrates, em suas defesas, parecem admitir a potência e a utilidade dos artifícios dramáticos e retóricos para a absolvição do réu. Contudo, mesmo conscientes de sua utilidade, ambos recusam-se, ou aparentam recusar-se a utilizá-los ${ }^{49}$.

Desde que o crime de Palamedes não possui nenhuma testemunha e não pode ser provado, o réu é obrigado a servir-se exclusivamente da racionalidade de seus argumentos para compor sua defesa. Devido à delicadeza de sua situação, Palamedes lembra seus jurados da necessidade de serem justos e não se permitirem levar por calúnias, pois as consequências poderiam ser terríveis. Por trás desse aviso de cuidado, pode-se ler certa crítica a um modelo jurídico que move, mesmo sem provas, processos que podem resultar na pena capital. De maneira semelhante, Sócrates, na Apologia, também se mostra crítico ao funcionamento da lei ateniense que permite que homens injustos levem homens inocentes "de ânimo leve” aos tribunais. A crítica de Sócrates se estende à curta duração de um julgamento sério. Ele parece afirmar que julgar um réu que, se culpado, seria condenado à morte, em apenas um dia, assemelha-se mais a um espetáculo trágico do que a uma instituição responsável pela promoção da justiça ${ }^{50}$.

49 “Quanto a vós, é preciso não prestar mais atenção nas palavras do que nas ações, nem dar mais valor às acusações do que às refutações, nem considerar um breve instante juiz mais sábio do que um longo período, tampouco julgar a calúnia mais digna de confiança do que a experiência. De fato, em relação a tudo é dever dos grandes homens terem a máxima precaução em não errar, quanto às decisões irremediáveis ainda mais do que quanto às remediáveis, pois essas (as primeiras) são possíveis de se reparar para os previdentes, mas irreparáveis para os imprevidentes. É disso que se trata quando os homens decidem sobre a morte de outro homem, precisamente o que acontece agora junto a vós". (Górgias, Apologia de Palamedes, parágrafo 34).

50 "Se, por meio das palavras, a verdade dos fatos pudesse surgir pura e límpida para os ouvintes, sem dúvida seria fácil tomar a decisão a partir do que foi dito. Uma vez que não é assim, vigiai meu corpo, usai o máximo de tempo e tomai a decisão de acordo com a verdade. Certamente correis um grande risco ao vos mostrardes injustos: o de destruir uma bela reputação e adquirir uma infame. Com efeito, para os homens de valor é preferível a morte a uma reputação infame, pois uma é o fim da vida, enquanto a outra, um mal que a acomete. 
Nesse momento do texto, já se encaminhando para o final, Palamedes retoma alguns aspectos que aparecem no início da defesa. Palamedes refere-se novamente à importância da honra e da vida honesta e, como Sócrates, adverte que, caso seja condenado, seu júri será reconhecido como injusto, tendo condenado um homem inocente à morte ${ }^{51}$. Ambos vinculam a sentença dos jurados com uma questão moral pessoal. Dessa forma, condená-los seria tornar-se injusto e, segundo o texto de Platão, o prejuízo maior se abateria sobre a alma do homem injusto. O verdadeiro caráter retórico se encontra justamente nessa dinâmica. Se os artifícios retóricos mais óbvios são destinados à multidão não refinada, esse mesmo comentário já é uma estratégia de persuasão. Sendo assim, para além das afirmações de verdade, justiça e honra, a retórica não pode deixar de ser utilizada, mesmo que sob determinados limites. A retórica, diante das influências a que a alma pode se submeter, pode ser uma ferramenta útil a serviço da razão, da verdade, da justiça e da honra. A retórica funcionaria, nesse caso, como um escudo frente a arbitrariedade que alimenta o funcionamento da democracia ateniense.

Tendo em vista os numerosos aspectos mencionados, foi possível observar que, em diversos momentos, o discurso de Palamedes se parece com o discurso de Sócrates no texto de Platão. As similaridades em questão parecem superar a formatação básica dos discursos forenses da retórica clássica. As declarações dos réus em questão assemelham-se logo no início, quando ambos, em suas respectivas defesas, declaram-se inaptos na arte do discurso forense. Os dois também afirmam que não possuem condições de possibilidade para de fato cometer os crimes dos quais são acusados, além de exporem a incompatibilidade de suas personalidades e de suas ações passadas com os crimes em questão. Tanto Sócrates quando Palamedes utilizam-se de argumentos de probabilidade para evidenciar a falta de meios que eles teriam para efetivar os cri-

Se me condenardes injustamente à morte, isso será evidente para muitos, pois não sou um desconhecido e vossa vilania será manifesta e conhecida de todos os helenos. Aos olhos de todos, sereis vós que carregareis a culpa manifesta dessa injustiça, não o acusador, pois a vós compete a decisão do processo. E não poderia haver erro maior do que esse. De fato, não cometerei um erro apenas em relação a mim e a meus antepassados, se determinardes uma sentença injusta, mas a vós mesmos, que tereis a consciência de ter cometido um ato terrível, ímpio, injusto e ilícito, condenando à morte um aliado, útil a vós e benfeitor da Hélade. Helenos condenando um heleno, sem ter sido provada qualquer injustiça manifesta ou qualquer acusação que fosse digna de crédito”. (Górgias, Apologia de Palamedes, parágrafo 35-36).

51 Cf. Apologia de Sócrates, (38c-d). 
mes em questão. Eles rememoram suas benfeitorias (sendo essas cívicas, militares e éticas) e afirmam sua utilidade para a cidade e a sua dedicação ao bem-estar coletivo, muitas vezes em detrimento de benefícios individuais. Ambos escolhem como suas testemunhas o próprio júri na condição de concidadãos e desfrutadores dos benefícios que forneceram. Ambos, de certa forma, banalizam o instituto da testemunha formal e acreditam-se superiores aos protocolos retóricos de praxe. Ambos acusam seus acusadores de não possuírem conhecimento sobre o que estão falando e assim não terem caso concreto contra eles. Ambos se recusam a implorar por suas vidas, trazer seus amigos e familiares a fim de causar piedade nos juízes e afirmam acreditar na justiça e na razão de suas palavras. Ambos afirmam que é mais vantajoso morrer do que viver uma vida desonrada e lembram que a morte, enquanto punição, não é eficaz, pois a natureza condenou todos os seres viventes à morte. Os dois protagonistas parecem não só acreditar, mas também utilizar a potência de artifícios retóricos ao mesmo tempo em que criticam a retórica forense como ferramenta de manipulação das emoções. Por fim, é muito significativo que Sócrates refira-se nominalmente a Palamedes na Apologia ${ }^{52}$. Sócrates não só o considera injustiçado como também afirma que gostaria de encontrá-lo no pós-morte para empreender com ele conversas filosóficas, ou seja, além de considerá-lo, tal como ele, alguém que foi injustamente punido, ele o considera um parceiro apto a conversas filosóficas, promovendo uma comparação direta de si com o herói mitológico, mas também gorgiano.

52 Cf. Apologia, 41 a-b. 


\section{REFERÊNCIAS BIBLIOGRÁFICAS}

GÓRGIAS. A defesa de Palamedes. [Tradução de Josiane T. Martinez]. São Paulo: UNICAMP, 2008.

GÓRGIAS. Elogio de Helena. [Apresentação e Tradução de Aldo Dinucci] Rio de Janeiro: Revista Ethica. V.16 n. 2, p. 201-212, 2009.

PLATÃO. Apologia de Sócrates/Críton. [Tradução Bilíngue de Carlos Alberto Nunes] Belém: Ed. UFPA, 2015.

PLATÃO. Apologia de Sócrates/Críton. [Tradução do grego, introdução e notas de Manuel de Oliveira Pulquério] Lisboa: Edições 70, 2013.

PLATÃO. Apologia de Sócrates. [Tradução, prefácio e notas de Pinharanda Gomes] Lisboa: Guimarães Editores, LDA, 1988.

PLATON. Apologie de Socrate/ Criton/ Phédon. [Traduction Nouvelle, introduction, notices et notes de Bernard et Renée Piettre] Librairie Générale Française, 1992.

PLATON. Apologie de Socrate/Criton. [Introductions et traductions inédites de Luc Brisson] Paris. GF Flammarion, 1997.

PLATON. Platon - oeuvres complètes: Apologie de Socrate. [Luc Brisson]. Éditions Flammarion, Paris, 2008 et 2011.

BELLIDO, A. M. Introdução e notas. In: Sofistas: testimonios y fragmentos. Madrid: Gredos, 1996.

CASSIN, Barbara. Ensaios sofísticos. $1^{\mathrm{a}}$ ed. São Paulo: Siciliano, 1990.

CASSIN, Barbara. O efeito sofístico: sofística, filosofia, retórica, literatura. Tradução dos documentos de Paulo Pinheiro. São Paulo: 34. 2005.

DORION, Louis-André. Le Gorgias et la défense de Socrate dans l'Apologie.

DINUCCI, Aldo. A sedução do lógos no Elogio de Helena de Górgias. Revista ARTEFILOSOFIA. Ouro Preto, n. 6, p. 135-146, 2009. Disponível em <http://www.raf.ifac.ufop. br/pdf/artefilosofia_06/artefilosofia_06_03_linguagem_poetica_lite ratura_o1_aldo_lopes_dinucci.pdf>. Acesso em 9 de dezembro de 2015 . 
DINUCCI, Aldo. Apresentação e tradução do Elogio de Helena de Górgias de Leontinos. Revista Ethica, Rio de Janeiro, v. 16, n. 2, p. 201-212, 2009.

SEVERO BUARQUE DE HOLANDA, Luisa. Aquiles como exemplo e contraexemplo: notas sobre Apologia de Sócrates, 28c. Anais de Filosofia Clássica (Online), v.11, p. 46-65, 2017.

SCHIAPPA, Edward. Did Plato coin Rhetorike? American Journal of Philology III, The John Hopkins University Press, 1990.

MATOSO, A. QUEIROZ. A. A apologia de Sócrates. Mimeo.

MCCOY, Marina. Platão - A retórica de filósofos e Sofistas. São Paulo: Madras Editora LTDA, 2010.

MCCOY, Marina. Perspectivism and the Philosophical Rhetoric of the Dialogue Form. Boston College. https://doi.org/10.14195/2183-4105_16_4 